\title{
Characterization studies for the recovery of land degraded by mining
}

\author{
R. M. Longo ${ }^{1}$, A. Í. Ribeiro ${ }^{2}$, W. J. de Melo $^{3}$, A. C. Demanboro ${ }^{1}$ \\ \& S. C. Bettine ${ }^{1}$ \\ ${ }^{I}$ Pontifícia Universidade Católica de Campinas, \\ Faculdade de Engenharia Ambiental, Brazil \\ ${ }^{2}$ Universidade Estadual Paulista "Júlio de Mesquita", \\ Campus Sorocaba, Brazil \\ ${ }^{3}$ Universidade Estadual Paulista "Júlio de Mesquita", \\ Campus Jaboticabal, Brazil
}

\begin{abstract}
The objective of the present work is to evaluate the differences that happened after the tin mining activity in an area of the Amazon forest and establishing planning actions for recovery of the degraded lands. Samples were collected, superficially, along a line with high forest, low forest, plows, reject dry and reject sandy materials. In each situation five samples were collected which worked as repetitions, in a total of 35 samples. In the collected samples physical analyses were accomplished: texture, soil's density and particles and mechanical resistance to penetration and chemical elements: $\mathrm{pH}\left(\mathrm{CaCl}_{2}\right)$; organic matter, $\mathrm{P}$, $\mathrm{K}, \mathrm{Ca}, \mathrm{Mg}, \mathrm{Al}, \mathrm{CEC}$ and $\mathrm{BS}$. The results showed that the process of tin extraction promoted significant alterations in the soil's properties studied. Parameters such as the organic matter, $\mathrm{P}$, the soil and particle's density were the most altered by the process of suppression of the original vegetation and extraction of the tin. Therefore, when it is intended to implant recovery projects in those areas, the soil's recovery should be prioritised for the success of the enterprise and the different degraded situations should be worked in different ways.

Keywords: mining activity, Amazon forest, degraded soil.
\end{abstract}




\section{Introduction}

Surface mining is, in general, an activity that can provoke a quite intense environmental degradation which tends to have a strong disturbing effect in the landscape because it requests the removal of the vegetation, of the soil and of the rocks that are above the mineral deposits. Thus, it is of great concern in the program of recovery of the area [1].

The Amazon ecosystem has been suffering an accelerated process of environmental degradation by the removal of vegetation for the accomplishment of agricultural projects, or for the disordered mineral and wood exploration. That process, begun in the 1960s decade and has been more active in recent years, with the elimination of great portions of the primary forest and a disregard for the effects to the botanical landscape. In this sense, several works have being published alerting of the environmental risks that can appear with the destruction of these formations [2-5].

On the other hand, those areas are extremely rich in biological and mineral resources and, for that reason wake up the economic interests not only for our Country but for the world-wide community. Brazil, a country undergoing development, means it has become evident that the rational exploration of the minerals becomes necessary to promote economic increments in the country. Thus, a controlled exploration and rationalization of the mineral resources of the Amazon area becomes acceptable, since the degraded areas provoked by these activities become appropriately recovered.

The present work's objective was to evaluate the physical and chemical properties along a line, consisting of high forest, short forest, mine pit, dry tailings and humid tailings, seeking to characterize the differences that happened after the tin mining activity in an area of Amazon forest. That work serves as a subsidy for future activities in the recovery of those areas, and once the soil analysis is completed where the recovery processes will be implemented, it is essential for the success of the enterprise to record the alterations that happened in tropical soils by the mining seen in Raij et al. [6].

\section{Material and methods}

The soil samples were collected in the National Forest (FLONA) of Jamari, administered by the Brazilian Institute of Environment and Renewable Mineral Resources - IBAMA and located $90 \mathrm{~km}$ outside the city of Porto Velho - RO, in the municipality of Itapuã d'Oeste. It presents an area of approximately $221.891,48$ ha, of which $90 \%$ are covered by Open Tropical Rain Forest [7].

In the surroundings of the area selected for study, the Rhodic Ferrasol and Xanthic Ferrasol $[8,9]$ are predominant, and the sampling was accomplished in Rhodic Ferrasol in accordance with a previous survey. The climate of the region is hot and wet, with an average temperature of $24^{\circ} \mathrm{C}$, presenting an annual precipitation of $2550 \mathrm{~mm}$, having its maximum in the months from December to March. The relative humidity is around 80 to $85 \%$, there being a clearly defined dry season with its most critical period between July and August. 


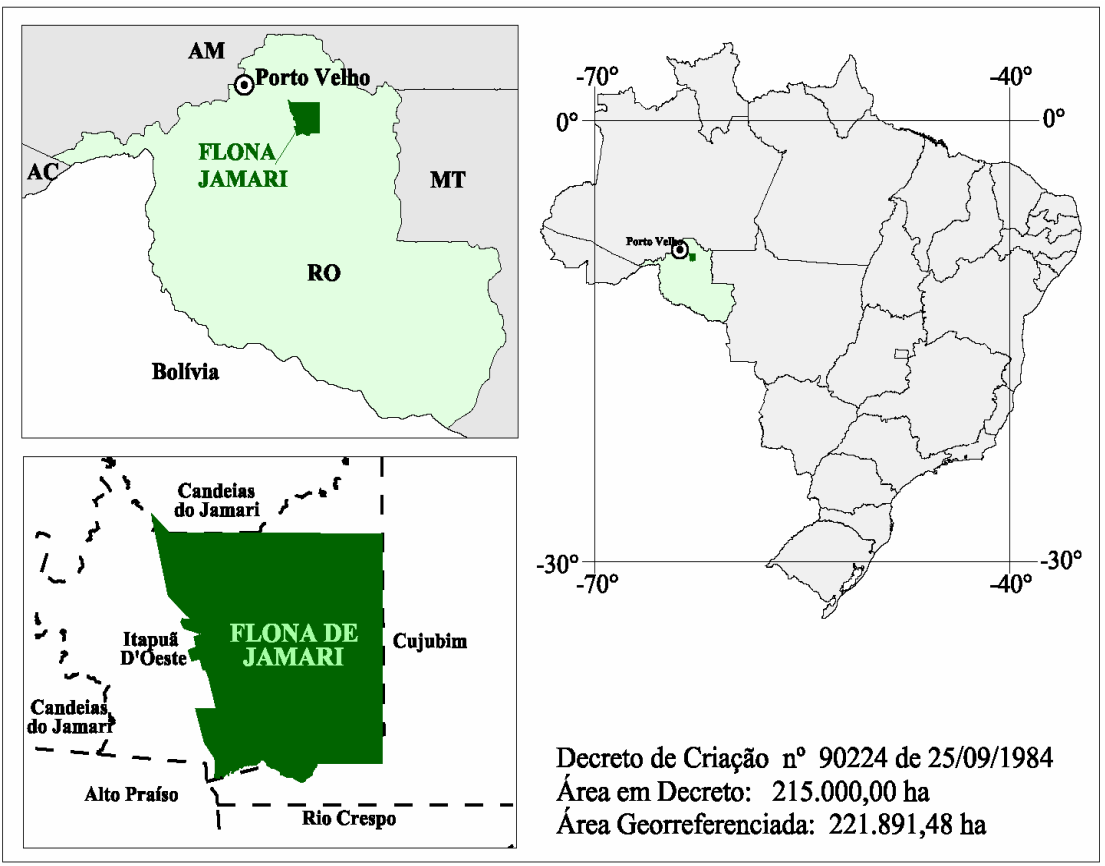

Figure 1: Location of the National Forest (FLONA) of Jamari/RO (IBAMA).

Since the beginning of the 1970s, tin has been exploited in the National Forest of Jamari, and these activities have been creating degraded areas that are being now recovered. The disturbed areas possess surfaces that range from 5 to 140 ha.

Soil samples were collected from five different sites on the tin mines spoil in: Rondônia, Brazil.

Samples 1-5: high forest

Sample 6-10: short forest

Sample 11-15: mine pit (mine 1)

Sample 16-20: dry tailings (mine 2)

Samples 21-25: humid tailings (mine 3)

In each place five samples were collected (twenty five in total) (Fig. 2).

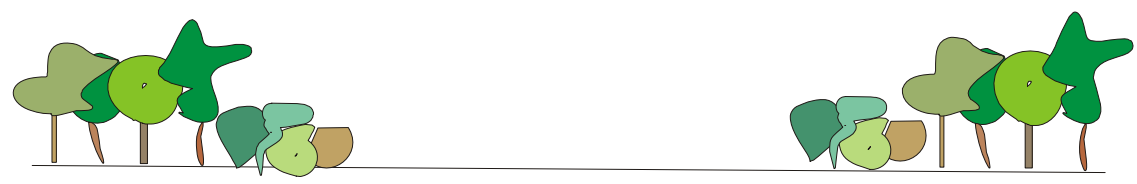

| High forest | Short forest | Mine 1 | Mine 2 | Mine 3 | Short forest | High forest |

Figure 2: $\quad$ Points of collected. 
The samples were collected superficially, with the help of an auger, in the layer between 0-20 cm, in regular intervals of 20 meters, a total of five samples composed by an area located between the UTM coordinates latitude $0900^{\prime} 00^{\prime \prime}$ to $930^{\prime} 00^{\prime \prime} \mathrm{S}$ and longitude $6244^{\prime} 05^{\prime \prime}$ to $6316^{\prime} 54^{\prime \prime} \mathrm{W}$, containing high forest, short forest, mining floor, dry tailing and sandy tailing..

The results were analyzed applying a variance analysis and the test $\mathrm{F}$ at $5 \%$ of probability. Physical parameters were analyzed: granulometric, soil's and particle's density in soil samples collected with a bottom ring. Numbers followed by the same letter are not significantly different at the 0.05 levels according to Turkey's.

The air dried soil were submitted to chemical analyses, being determined: $\mathrm{pH}$ $\left(\mathrm{CaCl}_{2}\right)$; organic matter by oxidation for the $\mathrm{H}_{2} \mathrm{SO}_{4}^{-}$; phosphorus $(\mathrm{P})$, potassium $(\mathrm{K})$, calcium $(\mathrm{Ca})$ and magnesium $(\mathrm{Mg})$ contents, extracted by the resin of ionic change; aluminum (Al) extracted by $\mathrm{KCl} 1 \mathrm{~N}$; cation exchange capacity (CEC) and base saturation (BS), were obtained by calculation. A description detailed of the analytic methods used can be seen in Raij et al. [6].

\section{Results and discussion}

The results obtained for the $\mathrm{pH}$ (Table 1) showed acid soils in all the studied situations, and with significant differences among the forest soil where larger acidity, proceeded by the short forest and for the different degraded situations, did not differ significantly to each other. According to Smyth (1996) the predominance of acid soils in firm earth places the acidity and the aluminum toxicity among the most frequent restrictions in Amazon's soil. The results indicated that, probably, the existent organic matter in the Forest soil and the processes involved in the extraction of the mineral, wash and separation of the material, promoted those differences.

Table 1: Chemical soil characteristics.

\begin{tabular}{c|c|c|c|ccc|c|c|c|c}
\hline \multirow{2}{*}{ Sample } & \multicolumn{10}{c}{ Characteristics } \\
\cline { 2 - 11 } & $\mathrm{pH}$ & $\mathrm{OM}$ & $\mathrm{P}$ & $\mathrm{K}$ & $\mathrm{Ca}$ & $\mathrm{Mg}$ & $\mathrm{H}+\mathrm{Al}$ & $\mathrm{CEC}$ & $\mathrm{SB}$ \\
\cline { 2 - 10 } & $\mathrm{CaCl}_{2}$ & $\mathrm{~d} \cdot \mathrm{dm}^{-}$ & $\mathrm{mg} \cdot \mathrm{dm}^{-3}$ & \multicolumn{3}{c}{$\mathrm{Mmol}_{\mathrm{c}} / \mathrm{dm}^{3}$} & & & $\%$ \\
\hline high forest & $3,8 \mathrm{a} *$ & $32 \mathrm{a}$ & $4,9 \mathrm{a}$ & $0,83 \mathrm{ab}$ & $5,1 \mathrm{a}$ & $1 \mathrm{a}$ & $80,9 \mathrm{a}$ & $8,1 \mathrm{a}$ & $8,1 \mathrm{a}$ \\
short forest & $4,1 \mathrm{~b}$ & $28,6 \mathrm{a}$ & $3,9 \mathrm{a}$ & $1,06 \mathrm{a}$ & $9,5 \mathrm{a}$ & $1 \mathrm{a}$ & $67,7 \mathrm{~b}$ & $17,7 \mathrm{~b}$ & $17,7 \mathrm{a}$ \\
mine pit & $4,4 \mathrm{c}$ & $2,4 \mathrm{~b}$ & $1 \mathrm{~b}$ & $0,38 \mathrm{~b}$ & $4,4 \mathrm{a}$ & $2 \mathrm{a}$ & $20,4 \mathrm{c}$ & 28,2 & $28,2 \mathrm{~b}$ \\
dry tailings & $4,6 \mathrm{c}$ & $3 \mathrm{~b}$ & $1,8 \mathrm{c}$ & $0,38 \mathrm{~b}$ & $4,4 \mathrm{a}$ & $2 \mathrm{a}$ & $14,6 \mathrm{c}$ & 21,6 & $21,6 \mathrm{~b}$ \\
humid tailings & $4,4 \mathrm{c}$ & $5 \mathrm{~b}$ & $1,6 \mathrm{c}$ & $0,38 \mathrm{~b}$ & $2,8 \mathrm{a}$ & $2 \mathrm{a}$ & $16,8 \mathrm{c}$ & 20,4 & $20,4 \mathrm{~b}$ \\
\hline
\end{tabular}

*In each column, numbers followed by the same letter are not significantly different at the 0.05 levels according to Turkey's.

The values of organic matter (Table 1), as expected, presented superior values in the forest in relation to the other situations by virtue of the process of extraction of the mineral that involves the suppression of the original vegetation, the wash, and separation of the collected material. Longo and Espíndola [10] making a study in the contents of C-organic and $\mathrm{N}$-total in areas of forest close to 
Porto Velho, proceeded by the pasture introduction, observed a gradual fall in the texts of those passing of the first for the second studied situation, agreeing with the results obtained by Espíndola et al. [11] who observed that in general the values of organic matter were quite vulnerable to the cultivation on account of being concentrated in the superficial layer of the soil. Few results were found in mining areas, the studies being more commonly obtained in agricultural areas. In Fig. 3 we can observe the dry tailing area and the forest.

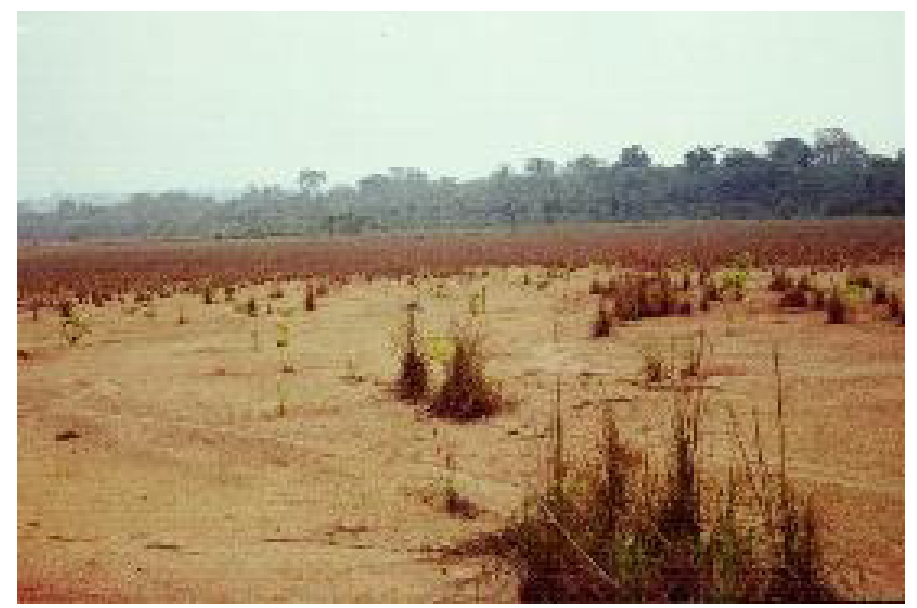

Figure 3: $\quad$ Tailings land.

Phosphorus $(\mathrm{P})$, potassium $(\mathrm{K})$, calcium $(\mathrm{Ca})$ and magnesium $(\mathrm{Mg})$ contents, can be found in Table 1. P contents came bottom in all the studied situations, being the largest values found in the forest situations, differing significantly from the other studied situations. According to Falesi [12] available $\mathrm{P}$ in the superficial layer of the soil drops drastically with the time after the establishment of agricultural activities as pasture. The $\mathrm{Ca}$ and $\mathrm{Mg}$ contents did not show significant differences among the studied situations, while the $\mathrm{K}$ presented superior values in the forest.

In relation to $\mathrm{SB}, \mathrm{S}, \mathrm{CEC}$ and $\mathrm{H}+\mathrm{Al}$ (Table 1), we can observe that the smallest values of CEC happened in the high forest and short forest situations differing significantly from the other studied situations, similar result was observed for SB, while the values of $\mathrm{S}$ did not differ in the different studied situations. $\mathrm{H}+\mathrm{Al}$ revealed significant differences among the studied situations, however largest values was observed in the soil under high forest and short forest, indicating that they are very acid and can present Al toxicity, similar results were observed by Longo et al. [10] in Rondônia's soils.

In relation of the sand, lime and clay percentages (Table 2) we can observe there were significant differences among the studied sites and the high forest, the short forest and the pit mine presented elevated texts of clay and lime, while in the tailings it was sandier. Espíndola et al. [11] observed a great textural variation in lands degraded by the tin extraction in Rondônia, being sandier in 
the "head" and loamier in the slope areas. We can observe like this that the different situations generated by the process of tin extraction: pit mine and tailings should be approached in a differentiated way in a recovery project.

Table 2: $\quad$ Physical soil characteristics.

\begin{tabular}{|c|c|c|c|c|c|}
\hline \multirow{3}{*}{ Sample } & \multicolumn{5}{|c|}{ Characteristics } \\
\hline & Sand & Lime & Clay & Soil Density & Particle Density \\
\hline & \multicolumn{3}{|c|}{$\%$} & \multicolumn{2}{|c|}{$\mathrm{g} / \mathrm{cm}_{3}$} \\
\hline high forest & $42,9 a$ & $23,5 \mathrm{a}$ & $39,8 \mathrm{a}$ & $1,05 \mathrm{a}$ & $2,5 \mathrm{a}$ \\
\hline short forest & $39,1 \mathrm{ab}$ & $19,8 \mathrm{ab}$ & $38,7 \mathrm{a}$ & $1,15 \mathrm{a}$ & $2,52 \mathrm{a}$ \\
\hline mine pit & $26,8 \mathrm{a}$ & $14,4 \mathrm{bc}$ & $58,8 b$ & $1,47 \mathrm{~b}$ & $2,61 \mathrm{~b}$ \\
\hline dry tailings & $72,6 \mathrm{c}$ & $11,6 \mathrm{c}$ & $15,8 \mathrm{c}$ & $1,33 \mathrm{ac}$ & $2,67 \mathrm{c}$ \\
\hline humid tailings & $66,8 \mathrm{c}$ & $14,8 \mathrm{c}$ & $18,4 \mathrm{c}$ & $1,12 \mathrm{a}$ & $2,67 \mathrm{c}$ \\
\hline
\end{tabular}

$*_{-}$In each column, numbers followed by the same letter are not significantly different at the 0.05 levels according to Turkey's

The soil and particle's density contents (Table 2) presented significant differences among the deferential studied situations being the smallest values found in the samples collected under high forest and short forest, that it probably suffered influence of the largest texts of organic matter found in these situations, as we can observe in Table 1.

After the first favorable results of the experiments, the work of recovery with the tested strategies began, with the objective of establishing a recovery plan for the degraded areas existing inside the FLONA and their monitoring. Ribeiro (2005) describes that the selection of the machinery and the execution of the operations in the different stages (topographical recovery, preparation, plantation and others) are indispensable factors for the initial success of the recovery techniques.

Today the company has been recovering about 300 ha of soil/year and it has already begun the plantation of native species of the Amazon Forest, producing annually approximately 200.000 plants. The alterations in the visual aspect of the areas and the results of the implanted program of monitoring (soil and vegetation) have been proving the accomplished progress and success.

\section{Conclusion}

The results showed that the process of tin extraction promoted significant alterations in the properties of the soils studied. Parameters as organic matter, phosphorus, soil and particle's density were the most altered by the process of suppression of the original vegetation and mineral extraction. In that way, upon intending to implant projects of recovery of those areas, the recovery of the soil should be prioritized for the success of the enterprise and the different degraded situations should be worked in a differentiated way. 


\section{Acknowledgements}

To Fundação de Amparo a Pesquisa do Estado de São Paulo (FAPESP), the Brascan and to the Brazilian Institute of the Environment and Mineral Resources you Renewed (IBAMA).

\section{References}

[1] Fontes, M.P.F. Estudo pedológico reduz impacto da mineração. Rev. Cetesb de tec. AMBIENTE, São Paulo, p. 58-61, 1991.Siqueira, 1994.

[2] Lisboa, P.L.B. Estudo florístico da vegetação arbórea de uma floresta secundária em Rondônia. Bol. Museu Paraense Emílio Goeldi, sér. Bot. 5(2): 145-162. 1989.

[3] Salomão, R.P. \& Lisboa, P.L.B. Análise ecológica da vegetação de uma floresta pluvial tropical de terra firme, Rondônia. Bol. Mus. Paraense Emílio Goeldi, Ser. Bot. 4(2), p. 195-233, 1988.

[4] Fearnide, P.M. Agricultura na Amazônia: Tipos de agricultura, padrão e tendências. Cadernos NAEA 10:197-252.UFPA, Belém, 1989.

[5] Fearnide, P.M. Amazônia: A fronteira agrícola 20 anos depois. Museu Paraense Emílio Goeldi, Belém/PA. 363, 1991.

[6] Raij, B. Van; Cantarella, H. Quaggio, J.A. Furlani, A.M.C. (Ed.) Recomendações de adubação e calagem para o Estado de São Paulo. Campinas: Instituto Agronômico de Campinas, 1996, 285p.

[7] Radambrasil. Folha SC-20. Porto Velho. Rio de Janeiro: Departamento Nacional de Produção Mineral, 1978. 661p. (Levantamento de Recursos Naturais, 16).

[8] EMBRAPA. Centro Nacional de Pesquisa de Solos (Rio de Janeiro, RJ). Sistema brasileiro de classificação de solos. Brasília: Embrapa produção de Informação, Rio de Janeiro, 1999. 412p.

[9] França, J.T. Estudos da sucessão secundária em áreas contíguas a mineração de cassiterita na Floresta Nacional do Jamari-RO. 1991. 169p. Dissertação (Mestrado) ESALQ/USP. Piracicaba.

[10] Longo, R.M., Espíndola, C.R. Alterações em características químicas de solos da região amazônica pela introdução de pastagens. ACTA AMAZÔNICA, 30(1): 71-80. 2000.

[11] Espíndola, C.R., Melo, W.J., Longo, R.M. Forest and soil degradation by tin minering. Abstracts of the International Symposium "Managing Forest Soils for Sustainable Productivity" Vila Real (Portugal), p. 215-214, 2000.

[12] Falesi, I.C. Ecossistemas de pastagens cultivadas na Amazônia brasileira. Belém, Embrapa/CPATU, Belém, (Boletim Técnico1), 1976., 193p. 1976.

[13] Ribeiro, A. I.; R. M. Longo., Melo W. J: Diagnosis of a Compacted Area for Mining through the Mechanical Resistance to the Penetration using Geostatistical Method in the Amazon Forest. WIT Transactions on Ecology and The Environment, v. 10, p. 41-49, 2004. 